\title{
Control of T lymphocyte fate decisions by PI3K signaling
}

\section{[version 1; peer review: 2 approved]}

\author{
Benjamin Murter, Lawrence P. Kane (iD) \\ Department of Immunology, University of Pittsburgh School of Medicine, Pittsburgh, PA, 15261, USA
}

V1 First published: 25 Sep 2020, 9(Faculty Rev):1171
https://doi.org/10.12688/f1000research.26928.1

Latest published: 25 Sep 2020, 9(Faculty Rev):1171

https://doi.org/10.12688/f1000research.26928.1

\section{Abstract}

Virtually all aspects of T and B lymphocyte development, homeostasis, activation, and effector function are impacted by the interaction of their clonally distributed antigen receptors with antigens encountered in their respective environments. Antigen receptors mediate their effects by modulating intracellular signaling pathways that ultimately impinge on the cytoskeleton, bioenergetic pathways, transcription, and translation. Although these signaling pathways are rather well described at this point, especially those steps that are most receptorproximal, how such pathways contribute to more quantitative aspects of lymphocyte function is still being elucidated. One of the signaling pathways that appears to be involved in this "tuning" process is controlled by the lipid kinase PI3K. Here we review recent key findings regarding both the triggering/enhancement of PI3K signals (via BCAP and ICOS) as well as their regulation (via PIK3IP1 and PHLPP) and how these signals integrate and determine cellular processes. Lymphocytes display tremendous functional plasticity, adjusting their metabolism and gene expression programs to specific conditions depending on their tissue of residence and the nature of the infectious threat to which they are responding. We give an overview of recent findings that have contributed to this model, with a focus on $T$ cells, including what has been learned from patients with gain-offunction mutations in PI3K as well as lessons from cancer immunotherapy approaches.

\section{Keywords}

Lymphocyte activation, signalling, lipid kinases, regulatory T cells

\section{Open Peer Review}

Approval Status

1

2

version 1

25 Sep 2020

Faculty Reviews are review articles written by the prestigious Members of Faculty Opinions. The articles are commissioned and peer reviewed before publication to ensure that the final, published version is comprehensive and accessible. The reviewers who approved the final version are listed with their names and affiliations.

1. Pam Schwartzberg, National Institute of Allergy and Infectious Diseases, Bethesda, USA

2. Klaus Okkenhaug, University of Cambridge, Cambridge, UK Any comments on the article can be found at the end of the article. 
Corresponding author: Lawrence P. Kane (Ikane@pitt.edu)

Author roles: Murter B: Conceptualization, Writing - Original Draft Preparation, Writing - Review \& Editing; Kane LP: Conceptualization, Funding Acquisition, Project Administration, Resources, Supervision, Writing - Review \& Editing

Competing interests: Lawrence Kane is a co-inventor on a pending patent application with the USPTO, regarding the translation of PIK3IP1 to modulate immunity. Benjamin Murter has no conflicts to declare.

Grant information: B. Murter is a member of the Program in Microbiology and Immunology and is supported by training grant T32CA082084 from National Institutes of Health (NIH)/National Cancer Institute (NCI) (PI: Vignali). Work in L. Kane's lab is supported in part by NIH awards R01AI138504, R01CA206517, and R01GM136148.

The funders had no role in study design, data collection and analysis, decision to publish, or preparation of the manuscript.

Copyright: $\odot 2020$ Murter B and Kane LP. This is an open access article distributed under the terms of the Creative Commons Attribution License, which permits unrestricted use, distribution, and reproduction in any medium, provided the original work is properly cited.

How to cite this article: Murter B and Kane LP. Control of T lymphocyte fate decisions by PI3K signaling [version 1; peer review: 2 approved] F1000Research 2020, 9(Faculty Rev):1171 https://doi.org/10.12688/f1000research.26928.1

First published: 25 Sep 2020, 9(Faculty Rev):1171 https://doi.org/10.12688/f1000research.26928.1 


\section{Antigen receptor signaling and $\mathrm{PI} 3 \mathrm{~K}$}

$\mathrm{T}$ and $\mathrm{B}$ cells are subject to a constant barrage of extracellular signals and cues, and the combined effects of these various signals decide the eventual functions and fate of these cells. These cellular cues, whether they are sensed through receptors for antigen ( $T$ cell receptor for antigen [TCR]), membrane immunoglobulin (mIg), cytokines, or other growth factors, are integrated in lymphocytes by signaling pathways that sustain and/or trigger the differentiation of these cells. The key elements of early signaling through the antigen receptors include tyrosine kinases of the Src and Syk families, phosphorylation of adaptor proteins, and recruitment and activation of PLC- $\gamma^{1,2}$. Activated PLC- $\gamma$ mediates the production of the critical second messengers diacylglycerol (DAG) and inositol tris-phosphate $\left(\mathrm{IP}_{3}\right)$, which lead to activation of PKC/Ras and calciumdependent signaling pathways, respectively.

The phosphatidylinositol 3-kinase (PI3K) signaling pathway, present in all eukaryotic cells, is another signaling pathway that acts as a key regulator of B and T cell fates. An overview of $\mathrm{PI} 3 \mathrm{~K}$ signaling pathways discussed in this review is shown in Figure 1.

There are three different classes of PI3K (I, II, and III) as well as various isoforms that comprise those classes. Here we will mainly address the class IA PI $3 \mathrm{~K} \operatorname{PI} 3 \mathrm{~K} \delta$, which is the isoform primarily activated by lymphocyte antigen receptors ${ }^{3,4}$. Class IA PI3Ks are heterodimeric kinases consisting of a regulatory subunit ( $\mathrm{p} 85 \alpha, \mathrm{p} 55 \alpha, \mathrm{p} 50 \alpha, \mathrm{p} 85 \beta$, or $\mathrm{p} 55 \gamma$ ) encoded by three genes (Pik3rl, Pik3r2, and Pik3r3) and a catalytic subunit (p110 $\alpha, \beta$, or $\delta$ ). Activation of the catalytic subunits downstream of receptor-tyrosine kinases (RTKs) leads to the catalytic conversion of the phospholipid $\mathrm{PI}(4,5) \mathrm{P}_{2}$ to the membrane-bound second messenger phosphoinositide 3,4,5-triphosphate $\left(\mathrm{PIP}_{3}\right)^{5}$. $\mathrm{PIP}_{3}$ recruits a number of pleckstrin homology (PH) domaincontaining proteins, including the serine/threonine $(\mathrm{S} / \mathrm{T}) \mathrm{PIP}_{3}-$ dependent kinase 1 (PDK1), which in turn phosphorylates and activates the S/T kinases of the Akt (aka protein kinase B, PKB) family (there are three Akt family members in mammals, Akt1-3). Activated receptors recruit class IA $\mathrm{PI} 3 \mathrm{Ks}$ via binding of one or more of their $\mathrm{SH} 2$ domains to phosphorylated tyrosines in such receptors. This binding appears to occur most efficiently at phosphorylated tyrosines within YXXM sequences ${ }^{6}$.

In $\mathrm{T}$ cells, the best-defined receptor for PI3K recruitment is the co-stimulatory protein $\mathrm{CD} 28$, a transmembrane protein that binds to B7 family proteins expressed by antigen-presenting cells (APCs). This interaction is critical for the activation of naïve $\mathrm{T}$ cells; however, the relevance of PI3K binding to the co-stimulatory activity of CD28 has been controversial ${ }^{7}$. This is, in part, because of the expanding understanding of the distinct and nonredundant role of ICOS (a CD28 family member) and its potent co-stimulation of the PI3K pathway in $\mathrm{T}$ cells ${ }^{8-10}$. Recent reports detailing how these family members promote such seemingly divergent $\mathrm{T}$ cell fates are discussed later.

In $\mathrm{B}$ cells, the recruitment of PI3K into the proximity of engaged antigen receptors mainly occurs through the transmembrane

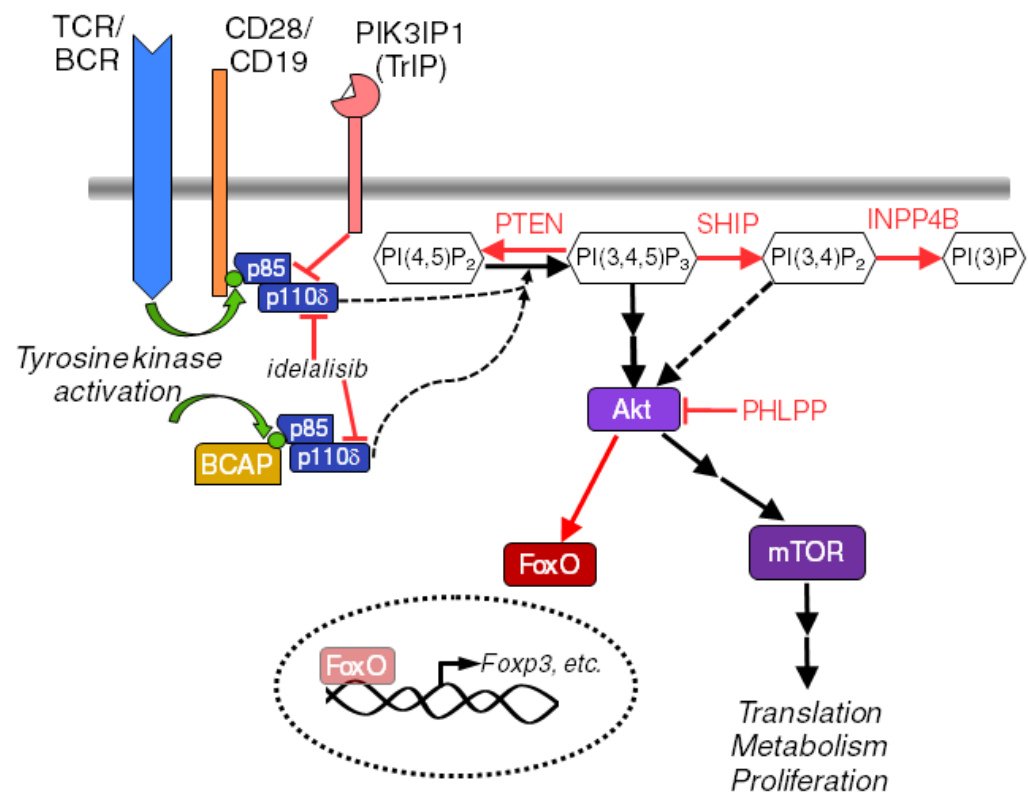

Figure 1. Major regulators and effectors of the phosphatidylinositol 3-kinase (PI3K) pathway in lymphocytes. Molecules and interactions discussed in the text are highlighted here. Activating events are indicated with black arrows. Inhibitory events are depicted with red lines or arrows. This is not an exhaustive model of the pathway. BCAP, B-cell adapter for PI3K; BCR, B cell receptor; INPP4B, inositol polyphosphate-4-phosphatase type II B; mTOR, mammalian target of rapamycin; PHLPP, PH domain and leucine-rich repeat protein phosphatase; PIK3IP1, PI3K interacting protein 1; PTEN, phosphatase and tensin homolog deleted on chromosome 10; SHIP, src homology 2 containing 5 '-inositol phosphatase; TCR, T cell receptor. 
protein CD19, which functions as part of a co-receptor complex that includes complement receptor 1 (CD21) and the tetraspan protein $\mathrm{CD} 81^{11}$. Coordination of this co-receptor signaling is performed in part by B-cell adapter for PI3K (BCAP), an adaptor protein capable of integrating multiple downstream signaling pathways ${ }^{12,13}$. This seems to be mediated by the ability of BCAP to associate with GRB2 and the p85 domain of the inactive form of PI3K (among other proteins) ${ }^{14,15}$. Despite its initial discovery in B cells and the absence of its expression in naïve $\mathrm{T}$ cells, BCAP is upregulated in $\mathrm{T}$ cells following activation, and we will highlight the recent discoveries involving $\mathrm{T}$ cells within the scope of this review ${ }^{16}$. These studies have revealed that BCAP plays a key role in the clonal expansion of effector and memory $\mathrm{CD} 8^{+} \mathrm{T}$ cells and in the differentiation of Th1 and Th17 helper $\mathrm{T}$ cells ${ }^{17}$. Together, these data suggest that BCAP upregulation in differentiated $\mathrm{T}$ cells serves to help assemble signaling complexes important for priming $\mathrm{T}$ cells for secondary responses to antigen. While these functions of BCAP are ascribed to its YXXM motifs and the recruitment and activation of $\mathrm{PI} 3 \mathrm{~K}$, the presence of other protein-protein interaction domains within BCAP suggests that it has the ability to coordinate signaling through multiple pathways.

It should be noted that a variety of receptors, including antigen, co-stimulatory, cytokine, chemokine, Toll-like, and growth factor receptors, are all known to activate PI3K signaling, and lymphocytes may receive input from many of these receptors concurrently ${ }^{18}$. This should be considered when interpreting the results of experiments to manipulate signaling through this pathway.

\section{Negative regulators of PI3K signaling in lymphocytes}

As with any signaling pathway that controls cellular growth and survival, the PI3K pathway is also subject to negative regulation. The majority of $\mathrm{PI} 3 \mathrm{~K}$ signal regulation is performed by two lipid-phosphatases: phosphatase and tensin homolog deleted on chromosome 10 (PTEN) and src homology 2 containing 5'-inositol phosphatase (SHIP), which convert $\mathrm{PIP}_{3}$ to $\mathrm{PI}(4,5) \mathrm{P}_{2}$ and $\mathrm{PI}(3,4) \mathrm{P}_{2}$, respectively. There is an additional negative regulator of $\mathrm{PIP}_{3}$, known as INPP4B (inositol polyphosphate-4-phosphatase type II B), which acts on the 4' phosphate, although this is less well understood and has not been studied in any detail in lymphocytes. Highlighting the importance of proper PI3K regulation, loss-of-function mutations in PTEN or SHIP have been linked to tumorigenesis ${ }^{19,20}$. Expression of PTEN appears to be particularly important, as homozygous loss of PTEN leads to early lethality, by embryonic day 7.5 in mice ${ }^{21}$. Interestingly, heterozygous loss of PTEN also leads to a distinct type of pathology, in the form of a group of hereditary disorders known as PTEN hamartoma tumor syndrome (PHTS). These patients display immune dysregulation due to enhanced PI3K/Akt signaling 22 , which was postulated to lead to thedisruption of $\mathrm{T}$ cell development.

Further study of PHTS patients led to the discovery of PH domain and leucine-rich repeat protein phosphatase (PHLPP) as a regulatory phosphatase downstream of PI3K and PTEN with a unique role in regulatory $\mathrm{T}$ cells (Tregs) ${ }^{23}$. PHLPP isoforms (PHLPP1 and PHLPP2) were shown to regulate the activity of the PI3K effector Akt through the dephosphorylation of S473 in $\mathrm{Akt}^{24}$. The expression of PHLPP has been shown to be particularly elevated in Treg cells, where it acts to preserve their suppressive phenotype in coordination with-and/or as compensation for-PTEN. More recently, a transmembrane inhibitor of $\mathrm{PI} 3 \mathrm{~K}, \mathrm{PI} 3 \mathrm{~K}$ interacting protein 1 (PIK3IP1) also known as transmembrane inhibitor of PI3K (TrIP), has been described $^{25,26}$. The maintenance of PI3K pathway homeostasis by these negative regulators, and their influence on lymphocyte differentiation, will be discussed further below.

\section{Effects of PI3K signaling on lymphocyte differentiation}

PI3K signaling is instrumental in promoting the inflammatory activity of $\mathrm{T}$ cells through phosphorylation of the FOXO transcription factors, leading to their nuclear exclusion and subsequent downregulation of cellular adhesion markers (e.g. CD62L and CCR7). This promotes trafficking of $\mathrm{T}$ cells out of secondary lymphoid tissues and into sites of inflammation. While nuclear exclusion of FOXO helps drive the inflammatory response, re-expression of FOXO1 is indispensable for $\mathrm{CD}^{+}$memory $\mathrm{T}$ cell maintenance and self-renewal ${ }^{27}$. Recent evidence demonstrating the upregulation of $\mathrm{BCAP}$ in $\mathrm{CD}^{+}$memory $\mathrm{T}$ cells contributes to our understanding of how these cells are primed to respond upon subsequent antigen encounter ${ }^{28}$.

PI3K signaling and some of its major downstream effectors such as mTOR and FOXO are necessary for the generation of helper $\mathrm{T}$ cell effectors (Th1, Th2, Th17), while conversely these factors are thought to be detrimental to the formation of Tregs ${ }^{29-32}$. Building on this seminal work, numerous studies have investigated the context-specific roles of these signals in both mouse models and human disease. Below we will discuss the requirement of PI $3 \mathrm{~K} \delta$ signaling in Tregs and speculate on how these cells have evolved to fine-tune PI3K/Akt signaling, which can be detrimental to their function. We will also examine recent discoveries in activated PI3K $\delta$ syndrome (APDS) and how PI3K dysregulation disproportionally affects Tfh cells and the subsequent B cell response. The PI3K pathway is highly regulated through downstream negative regulation, i.e. turnover of $\mathrm{PIP}_{3}$ or de-phosphorylation of downstream targets, e.g. Akt. In this review, we will discuss recent studies that demonstrate the role of a more novel membrane-bound inhibitor of PI3K, PIK3IP1, which operates upstream of any previously described regulators of this pathway. The implications of this novel membrane-bound regulator within the context of cancers as well as other studies regarding the use of PI3K inhibitors and their immunotherapeutic applications are discussed, as are some of the lessons that have been learned so far from these studies.

\section{Complex roles of PI3K and its effectors in regulatory $\mathrm{T}$ cell biology}

The role of PI3K signaling in the development, maintenance, and function of Tregs is not short on controversy. The strongest evidence that PI3K signaling limits Treg development comes 
from studies using the $\mathrm{p} 110 \delta^{\mathrm{D} 910 \mathrm{~A}}$ mouse model, in which $\mathrm{p} 110 \delta$ is inactivated by a point mutation ${ }^{33}$. Importantly, these mice avoid possible confounding effects of a total knockout of all $\mathrm{p} 110 \delta$ protein, an approach that results in secondary effects of reduced stability of associated PI3K regulatory subunits ${ }^{34}$. Thus, thymic-derived Tregs (also known as natural Tregs, nTregs) are found in much greater proportions in $\mathrm{p} 110 \delta^{\mathrm{D} 910 \mathrm{~A}}$ mice $^{35}$, at least in the thymus itself. By contrast, the spleen and lymph nodes of $\mathrm{p} 110 \delta^{\mathrm{D} 910 \mathrm{~A}}$ mice contain reduced numbers of Tregs, which are also less suppressive in vitro and fail to protect against experimental colitis in vivo ${ }^{35}$. Tregs can also be generated outside the thymus from naïve $\mathrm{CD}^{+} \mathrm{T}$ cells; these cells are termed "induced Tregs" or iTregs. This process can be modeled in vitro and indeed is more efficient under conditions of limiting PI3K/Akt/mTOR activity ${ }^{30,36,37}$.

Further highlighting a role for PI3K in limiting Treg development, inhibition or knockout of the mechanistic target of rapamycin (mTOR) complexes, which are downstream effectors of PI3K, results in de novo expression of Foxp3 in naïve $\mathrm{T}$ cells following initial activation ${ }^{31}$. These studies raise a paradox regarding the role of PI3K in Treg generation and suppressive function. Thus, partial inhibition of PI3K or its downstream effectors (Akt, mTOR) results in the promotion of Foxp3 expression upon stimulation, yet the complete loss of PI3K signaling results in inefficient Treg generation and function ${ }^{38}$. These seemingly contradictory effects of PI3K modulation may be explained mechanistically by understanding that the downstream biology depends on some combination of context, timing, and overall magnitude of PI3K signaling. This requirement for tight control also suggests the potential for future discovery of additional endogenous or therapeutic regulators that fine-tune PI3K within Tregs.

One potential mechanism by which Tregs uniquely integrate these seemingly competing PI3K signaling requirements is via the expression of PHLPP. As described above, Tregs have elevated expression of PHLPP compared to other T cell populations. Among other possible mechanisms, negative regulation of PI3K/Akt signaling by PHLPP could serve to prevent Aktmediated FOXO nuclear exclusion and thereby preserve Foxp3dependent transcriptional programs in the presence of PI3K signaling. This and other possible mechanisms, such as the influence of IL-2 signaling on the immunometabolism of Tregs, have been explored in greater detail by others ${ }^{32,39}$. Further support for the importance of tight PI3K signal regulation in Tregs comes from studies with selective PI3K inhibitors like the p110反 inhibitor idelalisib, which demonstrated preferential effects on Tregs in chronic lymphocytic leukemia (CLL) patients ${ }^{40}$. Overall, study of the influence of PI3K on Treg biology has revealed the uniquely sensitive nature of these cells to either the absence or the excessive activation of this pathway, especially in comparison to other $\mathrm{T}$ cell types. Clearly, further study of the relationship between PI3K and Treg biology is warranted.

\section{Lessons from activated PI3K $\delta$ syndrome}

Much of our understanding of PI3K signaling has come from a variety of reductionist approaches using pharmacological inhibition, knockdown, and knockout of different PI3K subunits. A number of recent studies evaluating the effects of overactive PI3K signaling in APDS patients have helped reveal additional aspects of PI3K function in immunity and beyond $^{41-43}$. Clinical presentation in this disease can be complex and variable; in one study of 53 patients, the most common findings were increased respiratory tract infections (98\%), lymphoid hyperplasia ( 60\%), herpesvirus infections (49\%), and autoimmunity $(42 \%)^{44}$. Facilitating the understanding of APDS, a mouse model of active PI3K ( $\left.\mathrm{Pik} 3 \mathrm{~cd}^{\mathrm{E} 1020 \mathrm{~K} /+}\right)$ reproduces many aspects of this disease ${ }^{45-49}$. Clinical and cellular aspects of APDS have been reviewed extensively elsewhere ${ }^{50-52}$, so we will touch on a few highlights here.

APDS can result from mutations in either PIK3R1 (p85

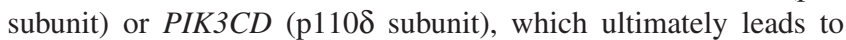
increased activity of PI3K $\delta$. Mechanistically, these mutations function either by disrupting the inhibitory contacts of p110 with $\mathrm{p} 85$ or by increasing the affinity of $\mathrm{p} 110 \delta$ for the plasma membrane, promoting its interaction with $\mathrm{PIP}_{2}^{53}$. Consistent with the known functions of PI3K signaling, APDS mutations result in enhanced activation of the Akt and mTOR kinase pathways and decreased activity of the FOXO1 transcription factor in $\mathrm{T}$ cells ${ }^{50}$. These changes are associated with increased $\mathrm{T}$ cell effector function and enhanced migration out of secondary lymphoid organs. It was also recently shown that APDS mutations result in enhanced cytokine production by effector $\mathrm{CD}^{+}$ helper $\mathrm{T}$ cells $^{50,54}$. However, consistent with a role for PI3K in limiting Treg development and function (discussed above), in vitro differentiation of naïve $\mathrm{CD}^{+} \mathrm{T}$ cells into inducible Tregs was less efficient with APDS T cells ${ }^{50}$.

The phenotype of $\mathrm{T}$ cells in mice or humans with activating mutations in PI3K presents a conundrum in that these mutations increase the sensitivity of $\mathrm{T}$ cells to activation while also resulting in immunodeficiency. As discussed below, chronic PI3K activity may actually promote $\mathrm{T}$ cell exhaustion and/or senescence, thereby predisposing affected individuals to chronic infection (see also 42,50,51). Most APDS patients present with an increase in circulating transitional B cells, as well as reduced numbers of class-switched B cells. In addition to clear B cell-intrinsic effects of APDS-associated mutations ${ }^{45-47,55}$, the defects in humoral immunity could also be due in part to the elevated numbers of Tfh cells and disorganized germinal centers found within the secondary lymphoid organs of APDS patients ${ }^{56}$. Within the germinal center, the signals that drive the Tfh program also initiate the expression of ICOS and migration towards the T-B border zone. ICOS expression is necessary for the formation of Tfh cells and cannot be compensated for by CD28, perhaps because ICOS is an even more potent activator of PI3K than is $\mathrm{CD} 28^{57}$.

Along with high levels of ICOS, Tfh cells also express high levels of PD-1, a known inhibitor of CD28-mediated signaling ${ }^{58}$. Therefore, ICOS expression coupled with high expression of PD-1 may constitute a mechanism by which PI3K signaling is orchestrated to differentially promote Tfh cell programs. These data corroborate earlier reports demonstrating that ligation 
of ICOS in the absence of TCR stimulation can still activate the PI3K pathway, which in this context helps explain the propensity towards Tfh differentiation in APDS patients ${ }^{8}$. While these studies demonstrate that overactive PI3K signaling drives an increase in $\mathrm{Tfh}$ cells, these cells do retain some FOXO1 activity. FOXO1 is a transcription factor simultaneously required for sustained ICOS expression and an inhibitor of Tfh differentiation ${ }^{59}$. Preite et al. went on to demonstrate that Pik3cd ${ }^{\mathrm{E} 1020 \mathrm{~K} /+} \mathrm{T}$ cells are able to bypass the need for ICOS phosphorylation and inactivation of FOXO1, thereby promoting the Tfh gene expression program ${ }^{45}$. Thus, study of APDS patients and mouse models of the disease has helped fill gaps in our understanding of how ICOS-mediated PI3K signaling promotes the Tfh and GC B cell programs.

\section{PIK3IP1/TrIP: a different kind of PI3K regulator}

As discussed above, the PI3K pathway is subject to significant negative regulation at the level of $\mathrm{PIP}_{3}$, with several phosphatases acting to increase turnover of this second messenger. However, a distinct type of PI3K negative regulator appears to act at the level of PI3K catalytic activity itself. The initial report of PIK3IP1 described it as a novel kringle domain-containing protein $^{60}$. Interestingly, the same study identified a sequence in the cytoplasmic domain of PIK3IP1 with significant homology to the inter-SH2 domain of the p85 PI3K adaptor proteins. Indeed, this paper suggested that PIK3IP1 was capable of binding to a complex containing both p85 and p110 proteins. Finally, evidence was shown in this paper that expression of PIK3IP1 could inhibit the activity of PI3K. Although a precise mechanism was not identified, this important study suggested that PIK3IP1 might function to interfere with the allosteric activation of PI3K. A follow-up study by the same group reported that transgenic overexpression of PIK3IP1 in the liver could suppress the development of hepatocellular carcinoma in a mouse model ${ }^{61}$, consistent with a pro-tumorigenic function of PI3K.

We became interested in the possible role of PIK3IP1 in lymphocytes as a result of the relatively high level of PIK3IP1 mRNA in $\mathrm{T}$ and $\mathrm{B}$ cells of both mice and humans based on public gene expression databases. We confirmed the expression of PIK3IP1 on primary murine T cells and two established $\mathrm{T}$ cell lines ${ }^{25}$. Particularly interesting is the expression of PIK3IP1 by Jurkat $\mathrm{T}$ cells, which are known to lack expression of two other PI3K negative regulators, PTEN and SHIP. We also showed that overexpression of PIK3IP1 could dampen PI3K signaling in response to anti-CD3/CD28 stimulation; conversely, siRNA-mediated silencing of endogenous PIK3IP1 led to enhanced $\mathrm{T}$ cell activation. These data revealed PIK3IP1 as a novel regulator of PI3K activity in lymphocytes and one uniquely positioned to act upstream of other known negative regulators of this pathway. Further studies revealed the importance of the extracellular kringle domain for PIK3IP1 inhibitory function $^{26}$. This finding raises the possibility that interaction with a ligand may modulate the ability of PIK3IP1 to control PI3K signaling in a context-dependent manner, although a specific ligand has yet to be identified.
A role for PIK3IP1 in $\mathrm{T}$ cell differentiation was demonstrated through in vitro helper $\mathrm{T}$ cell skewing experiments, where the absence of PIK3IP1 expression promoted a generally more inflammatory Th1 phenotype and was detrimental to the induction of Foxp3 $3^{+}$Tregs, which is consistent with work discussed above $^{30}$. These data were supported by an in vivo model of Listeria monocytogenes infection, where mice with $\mathrm{T}$ cellspecific knockout of PIK3IP1 showed a significantly lower bacterial burden compared to wild-type mice. Regulation of PIK3IP1 expression is only beginning to be understood, but recent evidence suggests that it is controlled in part by glutamine metabolism. Specifically, it was shown that glutaminolysis by $\mathrm{T}$ cells promotes a Th17 program, while restraining a Th1/CTL response, through direct effects on chromatin accessibility of multiple genes, including Pik3ip1 ${ }^{62}$. These results are consistent with our previous report that PIK3IP1 can restrain an inflammatory Th1 response ${ }^{26}$. The biological impact of this PI3K regulator has recently been expanded to include control of anti-tumor immunity ${ }^{63}$. This study employed mice with germline deficiency of PIK3IP1, which displayed significant resistance to the syngeneic transplantable tumors MC38 and $\mathrm{B} 16 \mathrm{~F} 10^{63}$. However, the cellular and molecular mechanisms underlying this enhanced tumor resistance are not fully understood. As this review has briefly discussed, the PIK3IP1 regulation may have differential cell- and tissuespecific roles that warrant further investigation using more targeted disruption, e.g. in effector T cells vs. Tregs.

\section{Modulation of PI3K to improve efficacy of immunotherapy}

Given the growing appreciation of how PI3K regulates lymphocyte cell fate decisions, there is emerging interest in targeting the PI3K pathway to improve cancer immunotherapy. While using PI3K inhibitors to directly inhibit the growth and survival of cancer cells is not a new concept ${ }^{64-66}$, the potential utility of combining such compounds with established immunotherapies to improve outcomes is more novel. One such approach has been the use of idelalisib (Zydelig®; Gilead), a PI3K $\delta$ inhibitor approved for second- or third-line treatment of several types of B cell leukemia/lymphoma. It should be noted that the drug carries an FDA-mandated black box warning, owing mainly to the significant risk of systemic toxicity that can impact multiple organ systems ${ }^{67,68}$. As with many immunomodulatory drugs, the use of idelalisib also comes with a risk of opportunistic infection, which in this case may be due, at least in part, to a delay in $\mathrm{CD}^{+}$differentiation and pathogen clearance ${ }^{69}$. This is consistent with murine studies showing that either knockout/ inactivation of the PI3K catalytic subunit $\mathrm{p} 110 \delta$ or the use of specific PI3K inhibitors (IC87114) led to impaired CD8 ${ }^{+} \mathrm{T}$ cell responses to both bacterial and viral infection ${ }^{70,71}$. In an attempt to circumvent these adverse events, Abu Eid et al. showed that inhibition of $\mathrm{PI} 3 \mathrm{~K} \delta$ ex vivo, prior to adoptive transfer of $\mathrm{CD}^{+} \mathrm{T}$ cells into tumor-bearing mice, led to a delay in the terminal differentiation of these cells and promoted their therapeutic activity ${ }^{69}$. This is consistent with previous findings suggesting a role for PI3K in limiting the formation of memory precursor $\mathrm{CD}^{+} \mathrm{T}$ cells in response to 
acute infection with lymphocytic choriomeningitis virus $(\mathrm{LCMV})^{72}$. Thus, context-dependent $\mathrm{PI} 3 \mathrm{~K} \delta$ inhibition may allow for more precise therapeutic modulation of the immune response, with fewer side effects, than traditional systemic inhibition.

Of course, $\mathrm{CD}^{+} \mathrm{T}$ cells may not be the only relevant target of PI3K inhibition in settings of immunotherapy. As discussed above, precise regulation of $\mathrm{PI} 3 \mathrm{~K}$ activity is required for Treg function and homeostasis. Thus, targeted disruption of p110 $\delta$ in Tregs has been shown to promote the regression of solid tumors in mice ${ }^{73}$. In addition, more recent studies have shown that relatively preferential inhibition of Treg function or expansion by $110 \delta$ inhibition in vivo may promote the anti-tumor response to solid or liquid tumors ${ }^{40,74-77}$. However, the interplay between PI3K inhibition and efficacy of other, now standard, immunotherapy agents (e.g. PD-1 blockade) remains unclear. As in any intervention that may modulate Treg function, tumor-specific approaches are desirable to avoid autoimmune sequelae as much as possible. Indeed, systemic inhibition of $\mathrm{p} 110 \delta$ in Tregs has recently been associated with autoimmunity in mouse models ${ }^{78}$ and has also been reported in clinical settings of PI3K use.

The inhibition of other members of the PI3K pathway, e.g. Akt and mTOR, has also been explored in settings of immunotherapy. Although partially inhibiting these kinases enhanced the acquisition of a memory $\mathrm{T}$ cell phenotype, this approach also limited $\mathrm{T}$ cell proliferation ${ }^{79}$. This report is consistent with previous findings that pharmacological inhibitors of $\mathrm{Akt}^{80}$ or of $\mathrm{mTORC} 1^{81}$ enhance $\mathrm{CD} 8^{+}$memory precursor formation after LCMV infection. With the recent report of a role for BCAP in regulating effector versus memory differentiation of $\mathrm{CD}^{+} \mathrm{T}$ cells ${ }^{28}$, it is possible that the key to improving CAR $\mathrm{T}$ cell therapy may be the identification of the right strategy to optimally "tune" PI3K signaling. As discussed above, the transmembrane protein PIK3IP1 represents a uniquely upstream regulator of the PI3K pathway whose impact on the effector/memory axis has yet to be fully understood.
Despite the still-incomplete mechanistic understanding of PIK3IP1, its utility as a potential target for cancer immunotherapy has already shown promise ${ }^{63}$.

While understanding the relationship between PI3K signaling and $\mathrm{T}$ cell biology can inform the development of new therapies, these same therapies can also help improve our understanding of $\mathrm{T}$ cell biology. Thus, in a follow-up study that examined the effects of the inhibition of PI3K $\delta$ (via idelalisib), the Treg compartment was found to be uniquely sensitive to PI3K $\delta$ inhibition when compared to other $\mathrm{T}$ cell types ${ }^{40}$. Tregs treated with idelalisib displayed greatly reduced proliferation and signaling activity, even at the lowest concentrations of inhibitor employed. These data reinforce the model that some level of $\mathrm{PI} 3 \mathrm{~K} \delta$ activity is required for maintaining the Treg phenotype, whereas other types of $\mathrm{T}$ cells (e.g. effector $\mathrm{T}$ cells) are less sensitive to changes in this pathway. This relative resistance of effector $\mathrm{T}$ cells to $\mathrm{PI} 3 \mathrm{~K} \delta$ modulation may be explained through their ability to maintain $\mathrm{PI} 3 \mathrm{~K}$ signaling via the other (semi)redundant $\mathrm{PI} 3 \mathrm{~K}$ isoforms $(\mathrm{PI} 3 \mathrm{~K} \alpha / \mathrm{PI} 3 \mathrm{~K} \beta)$, an idea that requires further exploration.

\section{Prospects for the future}

Thirty-five years after the discovery of the first PI3K activity by Cantley and colleagues, we have learned a tremendous amount about the function and regulation of this lipid kinase family and its downstream effectors. Study of $\mathrm{p} 110 \delta$, which is relatively lymphocyte specific, and its role in the disease APDS has driven significant recent progress in the translation of this pathway to the clinic. Current and future studies should further drive the clinical application of PI3K pathway modulators in $\mathrm{T}$ and $\mathrm{B}$ cell responses, providing evidence that more specific inhibitors can be identified to fine-tune responses in ways that avoid excessive immunosuppression or toxicity. In this regard, further elucidation of how PI3K activity is regulated by more subtle modulators of the pathway like PIK3IP1 and BCAP may lead to novel approaches to tune PI3K activity for enhancement or inhibition of lymphocyte responses to infection or cancer.

1. Gascoigne NRJ, Rybakin V, Acuto O, et al.: TCR Signal Strength and T Cell Development. Annu Rev Cell Dev Biol. 2016; 32: 327-48. PubMed Abstract | Publisher Full Text

2. Courtney AH, Lo WL, Weiss A: TCR Signaling: Mechanisms of Initiation and Propagation. Trends Biochem Sci. 2018; 43(2): 108-23. PubMed Abstract | Publisher Full Text | Free Full Text Faculty Opinions Recommendation

3. Okkenhaug K, Turner M, Gold MR: PI3K Signaling in B Cell and T Cell Biology. Front Immunol. 2014; 5: 557.

PubMed Abstract | Publisher Full Text | Free Full Text

4. Jean S, Kiger AA: Classes of phosphoinositide 3-kinases at a glance. J Cell Sci. 2014; 127(Pt 5): 923-8.

PubMed Abstract | Publisher Full Text | Free Full Text

5. Kane LP, Weiss A: The PI-3 kinase/Akt pathway and T cell activation: Pleiotropic pathways downstream of PIP3. Immunol Rev. 2003; 192: 7-20. PubMed Abstract | Publisher Full Text

6. Piccione E, Case RD, Domchek SM, et al.: Phosphatidylinositol 3-kinase p85 SH2 domain specificity defined by direct phosphopeptide/SH2 domain

binding. Biochemistry. 2002; 32(13): 3197-202.

PubMed Abstract | Publisher Full Text

7. Boomer JS, Green JM: An enigmatic tail of CD28 signaling. Cold Spring Harb Perspect Biol. 2010; 2(8): a002436.

PubMed Abstract | Publisher Full Text | Free Full Text

8. Gigoux M, Shang J, Pak Y, et al.: Inducible costimulator promotes helper T-cell differentiation through phosphoinositide 3-kinase. Proc Natl Acad Sci USA. 2009; 106(48): 20371-6.

PubMed Abstract | Publisher Full Text | Free Full Text

9. Choi YS, Kageyama R, Eto D, et al.: ICOS receptor instructs T follicular helper cell versus effector cell differentiation via induction of the helper cell versus effector cell differentiation via induction of
transcriptional repressor Bcl6. Immunity. 2011; 34(6): 932-46. PubMed Abstract | Publisher Full Text | Free Full Text | Faculty Opinions Recommendation

10. Zeng H, Cohen S, Guy C, et al.: mTORC1 and mTORC2 Kinase Signaling and Glucose Metabolism Drive Follicular Helper T Cell Differentiation. Immunity. 2016; 45(3): 540-54.

PubMed Abstract | Publisher Full Text | Free Full Text 
11. Fearon DT, Carroll MC: Regulation of $\mathbf{B}$ lymphocyte responses to foreign and self-antigens by the CD19/CD21 complex. Annu Rev Immunol. 2000; 18 : 393-422.

PubMed Abstract | Publisher Full Text

12. Okada T, Maeda A, Iwamatsu A, et al.: BCAP: the tyrosine kinase substrate that connects $B$ cell receptor to phosphoinositide 3-kinase activation. Immunity. 2000; 13(6): 817-27.

PubMed Abstract | Publisher Full Text

13. Inabe K, Kurosaki T: Tyrosine phosphorylation of B-cell adaptor for phosphoinositide 3-kinase is required for Akt activation in response to CD19 engagement. Blood. 2002; 99(2): 584-9.

PubMed Abstract | Publisher Full Text

14. Lauenstein JU, Udgata A, Bartram A, et al.: Phosphorylation of the multifunctional signal transducer B-cell adaptor protein (BCAP) promotes recruitment of multiple SH2/SH3 proteins including GRB2. J Biol Chem. 2019; 294(52): 19852-61.

PubMed Abstract | Publisher Full Text | Free Full Text |

Faculty Opinions Recommendation

15. Troutman TD, Hu W, Fulenchek S, et al: Role for B-cell adapter for PI3K (BCAP) as a signaling adapter linking Toll-like receptors (TLRs) to serine/threonine kinases PI3K/Akt. Proc Natl Acad Sci U S A. 2012; 109(1): 273-8. PubMed Abstract | Publisher Full Text | Free Full Text

16. Yamazaki T, Takeda K, Gotoh K, et al.: Essential Immunoregulatory Role for BCAP in B Cell Development and Function. J Exp Med. 2002; 195(5): $535-45$.

PubMed Abstract | Publisher Full Text | Free Full Text |

Faculty Opinions Recommendation

17. Deason K, Troutman TD, Jain A, et al.: BCAP links IL-1R to the PI3K-mTOR pathway and regulates pathogenic Th17 cell differentiation. J Exp Med. 2018; 215(9): 2413-28

PubMed Abstract | Publisher Full Text | Free Full Text | Faculty Opinions Recommendation

18. Saravia J, Raynor JL, Chapman NM, et al.: Signaling networks in immunometabolism. Cell Res. 2020; 30(4): 328-42. PubMed Abstract | Publisher Full Text | Free Full Text | Faculty Opinions Recommendation

19. Jiang BH, Liu LZ: PI3K/PTEN signaling in angiogenesis and tumorigenesis. Adv Cancer Res. 2009; 102: 19-65.

PubMed Abstract | Publisher Full Text | Free Full Text

20. Owusu-Brackett N, Shariati M, Meric-Bernstam F: Role of pi3k/akt/mtor in cancer signaling. In: Badve S, Kumar GL, editors. Predictive biomarkers in oncology: applications in precision medicine. Cham: Springer International Publishing: 2019; 263-70. Publisher Full Text

21. Di Cristofano A, Pesce B, Cordon-Cardo C, et al.: Pten is essential for embryonic development and tumour suppression. Nat Genet. 1998; 19(4): 348-55.

PubMed Abstract | Publisher Full Text

22. Neissing M, Ripken L, Schreibelt G, et al.: PTEN Hamartoma Tumor Syndrome and Immune Dysregulation. Transl Oncol. 2019; 12(2): 361-7. PubMed Abstract | Publisher Full Text | Free Full Text | Faculty Opinions Recommendation

23. Chen $\mathrm{HH}$, Händel $\mathrm{N}$, Ngeow J, et al.: Immune dysregulation in patients with PTEN hamartoma tumor syndrome: Analysis of FOXP3 regulatory T cells. J Allergy Clin Immunol. 2017; 139(2): 607-620.e15. PubMed Abstract | Publisher Full Text | Free Full Text

24. Gao T, Furnari F, Newton AC: PHLPP: A phosphatase that directly dephosphorylates Akt promotes apoptosis, and suppresses tumor growth. Mol Cell. 2005; 18(1): 13-24

PubMed Abstract | Publisher Full Text | Faculty Opinions Recommendation

25. DeFrances MC, Debelius DR, Cheng J, et al.: Inhibition of T-cell activation by PIK3IP1. Eur JImmunol. 2012; 42(10): 2754-9. PubMed Abstract | Publisher Full Text | Free Full Text

26. Uche UU, Piccirillo AR, Kataoka S, et al.: PIK3IP1/TrIP restricts activation of T cells through inhibition of PI3K/Akt. J Exp Med. 2018; 215(12): 3165-79. PubMed Abstract | Publisher Full Text | Free Full Text

27. Utzschneider DT, Delpoux A, Wieland D, et al:: Active Maintenance of T Cell Memory in Acute and Chronic Viral Infection Depends on Continuous Expression of FOXO1. Cell Rep. 2018; 22(13): 3454-67. PubMed Abstract | Publisher Full Text | Free Full Text | Faculty Opinions Recommendation

28. Singh MD, Ni M, Sullivan JM, et al.: B cell adaptor for PI3-kinase (BCAP) modulates CD8+ effector and memory T cell differentiation. J Exp Med. 2018; 215(9): 2429-43

PubMed Abstract | Publisher Full Text | Free Full Text | Faculty Opinions Recommendation

29. Delgoffe GM, Kole TP, Zheng Y, et al:: The mTOR Kinase Differentially Regulates Effector and Regulatory T Cell Lineage Commitment. Immunity. 2009; 30(6): 832-44.

PubMed Abstract | Publisher Full Text | Free Full Text |

Faculty Opinions Recommendation
30. Sauer S, Bruno L, Hertweck A, et al.: T cell receptor signaling controls Foxp3 expression via PI3K, Akt and mTOR. Proc Natl Acad Sci U S A. 2008; 105(22): 7797-802.

PubMed Abstract | Publisher Full Text | Free Full Text

31. Gamper CJ, Powell JD: All PI3Kinase signaling is not mTOR: Dissecting mTORdependent and independent signaling pathways in T cells. Front Immunol. 2012; 3: 312.

PubMed Abstract | Publisher Full Text | Free Full Text

32. Soond DR, Slack ECM, Garden OA, et al.: Does the PI3K pathway promote or antagonize regulatory $\mathrm{T}$ cell development and function? Front Immunol. 2012; 3: 244.

PubMed Abstract | Publisher Full Text | Free Full Text

33. Okkenhaug K, Bilancio A, Farjot G, et al.: Impaired B and T cell antigen receptor signaling in p110delta PI 3-kinase mutant mice. Science. 2002; 297(5583): 1031-4.

PubMed Abstract | Publisher Full Text | Faculty Opinions Recommendation

34. Brachmann SM, Ueki K, Engelman JA, et al.: Phosphoinositide 3-Kinase Catalytic Subunit Deletion and Regulatory Subunit Deletion Have Opposite Effects on Insulin Sensitivity in Mice. Mol Cell Biol. 2005; 25(5): 1596-607. PubMed Abstract | Publisher Full Text | Free Full Text

35. Patton DT, Garden OA, Pearce WP, et al.: Cutting edge: The phosphoinositide 3-kinase p110 delta is critical for the function of CD4+CD25+Foxp3+ regulatory T cells. J Immunol. 2006; 177(10): 6598-602. PubMed Abstract | Publisher Full Text

36. Etemire E, Krull M, Hasenberg M, et al:: Transiently Reduced PI3K/Akt Activity Drives the Development of Regulatory Function in Antigen-Stimulated Naïve T-Cells. PLoS One. 2013; 8(7): e68378.

PubMed Abstract | Publisher Full Text | Free Full Text

37. Haxhinasto $S$, Mathis $D$, Benoist C: The AKT-mTOR axis regulates de novo differentiation of CD4+Foxp3+ cells. J Exp Med. 2008; 205(3): 565-74. PubMed Abstract | Publisher Full Text | Free Full Text | Faculty Opinions Recommendation

38. Zeng $\mathrm{H}$, Yang $\mathrm{K}$, Cloer $\mathrm{C}$, et al:: mTORC1 couples immune signals and metabolic programming to establish Treg-cell function. Nature. 2013; 499(7459): 485-90.

PubMed Abstract | Publisher Full Text | Free Full Text Faculty Opinions Recommendation

39. Fan MY, Turka LA: Immunometabolism and PI(3)K Signaling As a Link between IL-2, Foxp3 Expression, and Suppressor Function in Regulatory $T$ Cells. Front Immunol. 2018; 9: 69

PubMed Abstract | Publisher Full Text | Free Full Text |

Faculty Opinions Recommendation

40. Chellappa S, Kushekhar K, Munthe LA, et al.: The PI3K p1108 Isoform Inhibitor Idelalisib Preferentially Inhibits Human Regulatory T Cell Function. J Immunol. 2019; 202(5): 1397-405.

PubMed Abstract | Publisher Full Text | Faculty Opinions Recommendation

41. Angulo I, Vadas O, Garçon F, et al.: Phosphoinositide 3-kinase $\delta$ gene mutation predisposes to respiratory infection and airway damage. Science. 2013; 342(6160): 866-71

PubMed Abstract | Publisher Full Text | Free Full Text Faculty Opinions Recommendation

42. Elkaim E, Neven B, Bruneau J, et al.: Clinical and immunologic phenotype associated with activated phosphoinositide 3-kinase $\delta$ syndrome 2: A cohort study. J Allergy Clin Immunol. 2016; 138(1): 210-218.e9. Publisher Full Text

43. Lucas CL, Zhang Y, Venida A, et al:: Heterozygous splice mutation in PIK3R1 causes human immunodeficiency with lymphoproliferation due to dominant activation of PI3K. J Exp Med. 2014; 211(13): 2537-47. PubMed Abstract | Publisher Full Text | Free Full Text

44. Coulter TI, Chandra A, Bacon CM, et al.: Clinical spectrum and features of activated phosphoinositide 3-kinase $\delta$ syndrome: A large patient cohort study. J Allergy Clin Immunol. 2017; 139(2): 597-606.e4.

PubMed Abstract | Publisher Full Text | Free Full Text

45. CPreite S, Cannons JL, Radtke AJ, et al.: Hyperactivated PI3K $\delta$ promotes self and commensal reactivity at the expense of optimal humoral immunity. Nat Immunol. 2018; 19(9): 986-1000.

PubMed Abstract | Publisher Full Text | Free Full Text |

Faculty Opinions Recommendation

46. Wray-Dutra MN, Al Qureshah F, Metzler G, et al: Activated PIK3CD drives innate $B$ cell expansion yet limits B cell-intrinsic immune responses. J Exp Med. 2018; 215(10): 2485-96.

PubMed Abstract | Publisher Full Text | Free Full Text Faculty Opinions Recommendation

47. Avery DT, Kane A, Nguyen T, et al.: Germline-activating mutations in PIK3CD compromise B cell development and function.J Exp Med. 2018, 215(8): 2073-95.

PubMed Abstract | Publisher Full Text | Free Full Text |

Faculty Opinions Recommendation

48. N Stark AK, Chandra A, Chakraborty K, et al.: PI3K $\delta$ hyper-activation promotes development of B cells that exacerbate Streptococcus 
pneumoniae infection in an antibody-independent manner. Nat Commun. 2018; 9(1): 3174

PubMed Abstract | Publisher Full Text | Free Full Text |

Faculty Opinions Recommendation

49. Jia Y, Yang Q, Wang Y, et al.: Hyperactive PI3K $\delta$ predisposes naive T cells to activation via aerobic glycolysis programs. Cell Mol Immunol. 2020. PubMed Abstract | Publisher Full Text | Faculty Opinions Recommendation

50. Preite S, Gomez-Rodriguez J, Cannons JL, et al.: T and B-cell signaling in activated PI3K delta syndrome: From immunodeficiency to autoimmunity. Immunol Rev. 2019; 291(1): 154-73.

PubMed Abstract | Publisher Full Text | Faculty Opinions Recommendation

51. Lucas CL, Chandra A, Nejentsev S, et al.: PI3K $\delta$ and primary immunodeficiencies. Nat Rev Immunol. 2016: 16(11): 702-14. PubMed Abstract | Publisher Full Text | Free Full Text

52. Michalovich D, Nejentsev S: Activated PI3 Kinase Delta Syndrome: From Genetics to Therapy. Front Immunol. 2018; 9: 129. PubMed Abstract | Publisher Full Text | Free Full Text | Faculty Opinions Recommendation

53. Dornan GL, Siempelkamp BD, Jenkins ML, et al.: Conformational disruption of PI3K regulation by immunodeficiency mutations in PIK3CD and PIK3R1. Proc Natl Acad Sci U S A. 2017; 114(8): 1982-7. PubMed Abstract | Publisher Full Text | Free Full Text Faculty Opinions Recommendation

54. Bier J, Rao G, Payne K, et al.: Activating mutations in PIK3CD disrupt the differentiation and function of human and murine CD4+ T cells. J Allergy Clin Immunol. 2019; 144(1): 236-53.

PubMed Abstract | Publisher Full Text | Free Full Text |

Faculty Opinions Recommendation

55. Lau A, Avery DT, Jackson K, et al.: Activated PI3K $\delta$ breaches multiple B cell tolerance checkpoints and causes autoantibody production. $J$ Exp Med. 2020; 217(2): e20191336.

PubMed Abstract | Publisher Full Text | Free Full Text

Faculty Opinions Recommendation

56. CPreite S, Huang B, Cannons JL, et al.: PI3K Orchestrates T Follicular Helper Cell Differentiation in a Context Dependent Manner: Implications for Autoimmunity. Front Immunol. 2019; 9: 3079.

PubMed Abstract | Publisher Full Text | Free Full Text |

Faculty Opinions Recommendation

57. Parry RV, Rumbley CA, Vandenberghe LH, et al.: CD28 and inducible costimulatory protein Src homology 2 binding domains show distinct regulation of phosphatidylinositol 3-kinase, Bcl-xL, and IL-2 expression in primary human CD4 T lymphocytes. J Immunol. 2003; 171(1): 166-74. PubMed Abstract | Publisher Full Text

58. N Shi J, Hou S, Fang Q, et al.: PD-1 Controls Follicular T Helper Cell Positioning and Function. Immunity. 2018; 49(2): 264-274.e4. PubMed Abstract | Publisher Full Text | Free Full Text | Faculty Opinions Recommendation

59. Stone EL, Pepper M, Katayama CD, et al.: ICOS coreceptor signaling inactivates the transcription factor FOXO1 to promote Tfh cell differentiation. Immunity. 2015; 42(2): 239-51. PubMed Abstract | Publisher Full Text | Free Full Text

60. Zhu Z, He X, Johnson C, et al:: PI3K is negatively regulated by PIK3IP1, a novel p110 interacting protein. Biochem Biophys Res Commun. 2007; 358(1): 66-72.

PubMed Abstract | Publisher Full Text | Free Full Text

61. He X, Zhu Z, Johnson C, et al.: PIK3IP1, a negative regulator of PI3K, suppresses the development of hepatocellular carcinoma. Cancer Res. 2008; 68(14): 5591-8.

PubMed Abstract | Publisher Full Text | Free Full Text

62. Nohnson MO, Wolf MM, Madden MZ, et al.: Distinct Regulation of Th17 and Th1 Cell Differentiation by Glutaminase-Dependent Metabolism. Cell. 2018: 175(7): 1780-1795.e19.

PubMed Abstract | Publisher Full Text | Free Full Text Faculty Opinions Recommendation

63. Chen $Y$, Wang J, Wang $X$, et al.: Pik3ip1 Is a Negative Immune Regulator that Inhibits Antitumor T cell Immunity. Clin Cancer Res. 2019; 25(20): 6180-6194.

PubMed Abstract | Publisher Full Text | Faculty Opinions Recommendation

64. CYang J, Nie J, Ma X, et al.: Targeting PI3K in cancer: Mechanisms and advances in clinical trials. Mol Cancer. 2019; 18(1): 26. PubMed Abstract | Publisher Full Text | Free Full Text | Faculty Opinions Recommendation
65. Stark AK, Sriskantharajah S, Hessel EM, et al.: PI3K inhibitors in inflammation, autoimmunity and cancer. Curr Opin Pharmacol. 2015; 23: 82-91. PubMed Abstract | Publisher Full Text | Free Full Text

66. Pons-Tostivint E, Thibault B, Guillermet-Guibert J: Targeting PI3K Signaling in Combination Cancer Therapy. Trends Cancer. 2017; 3(6): 454-69.

PubMed Abstract | Publisher Full Text

67. Coutré SE, Barrientos JC, Brown JR, et al.: Management of adverse events associated with idelalisib treatment: Expert panel opinion. Leuk Lymphoma. 2015; 56(10): 2779-86.

PubMed Abstract | Publisher Full Text | Free Full Text

68. Sharman JP, Coutre SE, Furman RR, et al.: Final Results of a Randomized Phase III Study of Rituximab With or Without Idelalisib Followed by OpenLabel Idelalisib in Patients With Relapsed Chronic Lymphocytic Leukemia. J Clin Oncol. 2019; 37(16): 1391-402.

PubMed Abstract | Publisher Full Text | Faculty Opinions Recommendation

69. Abu Eid R, Ahmad S, Lin Y, et al.: Enhanced Therapeutic Efficacy and Memory of Tumor-Specific CD8 T Cells by Ex Vivo PI3K- $\delta$ Inhibition. Cancer Res. 2017; 77(15): 4135-45

PubMed Abstract | Publisher Full Text

70. Gracias DT, Boesteanu AC, Fraietta JA, et al.: Phosphatidylinositol 3-Kinase p110 $\delta$ Isoform Regulates CD8+ T Cell Responses during Acute Viral and Intracellular Bacterial Infections. J Immunol. 2016; 196(3): 1186-98. PubMed Abstract | Publisher Full Text | Free Full Text | Faculty Opinions Recommendation

71. Pearce VQ, Bouabe $H$, MacQueen AR, et al.: PI3K $\delta$ Regulates the Magnitude of CD8 + T Cell Responses after Challenge with Listeria monocytogenes. Immunol. 2015; 195(7): 3206-17. PubMed Abstract | Publisher Full Text | Free Full Text

72. Hand TW, Cui W, Jung YW, et al.: Differential effects of STAT5 and PI3K/AKT signaling on effector and memory CD8 T-cell survival. Proc Natl Acad Sci US A. 2010; 107(38): 16601-6.

PubMed Abstract | Publisher Full Text | Free Full Text

73. Ali K, Soond DR, Piñeiro R, et al:: Inactivation of PI(3)K p110 $\delta$ breaks regulatory T-cell-mediated immune tolerance to cancer. Nature. 2014; 510(7505): 407-11.

PubMed Abstract | Publisher Full Text | Free Full Text Faculty Opinions Recommendation

74. Dong S, Harrington BK, Hu EY, et al.: PI3K p1108 inactivation antagonizes chronic lymphocytic leukemia and reverses $\mathrm{T}$ cell immune suppression. J Clin Invest. 2019; 129(1): 122-36.

PubMed Abstract | Publisher Full Text | Free Full Text | Faculty Opinions Recommendation

75. Hanna BS, Roessner PM, Scheffold A, et al.: PI3K $\delta$ inhibition modulates regulatory and effector T-cell differentiation and function in chronic lymphocytic leukemia. Leukemia. 2019; 33(6): 1427-38. PubMed Abstract | Publisher Full Text | Faculty Opinions Recommendation

76. Lim EL, Cugliandolo FM, Rosner DR, et al.: Phosphoinositide 3-kinase $\delta$ inhibition promotes antitumor responses but antagonizes checkpoint inhibitors. JCI Insight. 2018; 3(11): e120626. PubMed Abstract | Publisher Full Text | Free Full Text

77. Ahmad S, Abu-Eid R, Shrimali R, et al.: Differential PI3Kס Signaling in CD4 + T-cell Subsets Enables Selective Targeting of T Regulatory Cells to Enhance Cancer Immunotherapy. Cancer Res. 2017; 77(8): 1892-904. PubMed Abstract | Publisher Full Text

78. C Stark AK, Davenport ECM, Patton DT, et al.: Loss of Phosphatidylinositol 3-Kinase Activity in Regulatory T Cells Leads to Neuronal Inflammation. Immunol. 2020; 205(1): 78-89.

PubMed Abstract | Publisher Full Text | Free Full Text Faculty Opinions Recommendation

79. Zheng W, O'Hear CE, Alli R, et al.: PI3K orchestration of the in vivo persistence of chimeric antigen receptor-modified T cells. Leukemia. 2018; 32(5): 1157-67.

PubMed Abstract | Publisher Full Text | Free Full Text | Faculty Opinions Recommendation

80. Kim EH, Sullivan JA, Plisch EH, et al.: Signal Integration by Akt Regulates CD8 T Cell Effector and Memory Differentiation. The Journal of Immunology. 2012; 188(9): 4305-14.

PubMed Abstract | Publisher Full Text | Free Full Text

81. Araki K, Turner AP, Shaffer VO, et al.: mTOR regulates memory CD8 T-cel differentiation. Nature. 2009; 460(7251): 108-12. PubMed Abstract | Publisher Full Text | Free Full Text | Faculty Opinions Recommendation 


\section{Open Peer Review}

\section{Current Peer Review Status:}

\section{Editorial Note on the Review Process}

Faculty Reviews are review articles written by the prestigious Members of Faculty Opinions. The articles are commissioned and peer reviewed before publication to ensure that the final, published version is comprehensive and accessible. The reviewers who approved the final version are listed with their names and affiliations.

\section{The reviewers who approved this article are:}

\section{Version 1}

\section{Klaus Okkenhaug}

Department of Pathology, University of Cambridge, Cambridge, UK

Competing Interests: No competing interests were disclosed.

\section{Pam Schwartzberg}

National Institute of Allergy and Infectious Diseases, Bethesda, MD, USA

Competing Interests: No competing interests were disclosed.

The benefits of publishing with F1000Research:

- Your article is published within days, with no editorial bias

- You can publish traditional articles, null/negative results, case reports, data notes and more

- The peer review process is transparent and collaborative

- Your article is indexed in PubMed after passing peer review

- Dedicated customer support at every stage

For pre-submission enquiries, contact research@f1000.com 